\title{
Research on the Application of Political Teaching Under the Network Platform
}

\author{
Yingli Pan \\ Ideological and Political Department Xi'an Peihua University Xi'an, Shaanxi province \\ 79255432@qq.com
}

Keywords: Ideological; Political cours; Network; Countermeasures

\begin{abstract}
With the advent of the era of network, information technology has penetrated into many fields such as politics, economy, culture and so on. Human's production mode, life style and learning way have changed greatly. The traditional educational mode has been unable to meet the diverse needs of students. Our educational reform and development are facing unprecedented challenges. The driving point of educational reform is to drive educational modernization with educational information. In this context, the ideological and political theory needs a new teaching model to make up for the shortcomings of the traditional teaching model. After a series of explorations, it is found that the teaching mode, which is based on classroom teaching and the network teaching is supplemented, is a new model in line with the requirements of the times. The network teaching platform of the ideological and political course has emerged as a new part of the network teaching.

The network teaching platform is first appeared in foreign countries. At present, there are two main network teaching platforms in the world, including commercial platform and open source platform. The main business platforms are Learning Space, Virtual, Blackboard, Top Class, etc.; open source platforms include Atutor, Sakai, Moodle, LAMS, Claroline and so on. The network teaching platform contains many languages and is easy to use, so it has been widely used in the world.
\end{abstract}

\section{The Development of the Network Teaching Platform Lays the Foundation for the Network Teaching Platform of the Ideological and Political Course}

At present, the network teaching platform of Ideological and political course has made remarkable achievements: from the original resource storage and learning management platform to the comprehensive platform of network teaching nowadays, In the platform, teachers can publish curriculum contents, students can download data and learn curriculum knowledge, and teachers and students can interact on online teaching integrated platform. The network teaching platform includes functions such as teacher guidance, interaction between teachers and students, and campus network services, and has the characteristics of resource richness, interaction, convenience and openness. The multi-function of Ideological and political education network teaching platform enriches the teaching content and teaching form, and makes up for the shortcomings of traditional ideological and political course, and gradually forms a teaching mode mainly based on classroom teaching, supplemented by online teaching platform, closely integrated online and offline, and complemented.

\section{The Influence Factors of the Problems in the Application of the Network Teaching Platform in the Ideological and Political Course}

This paper adopts comprehensive index method analysis, the qualitative and quantitative issues, determine the weight of each factor level index through expert scoring method, student questionnaire survey to determine the value of the two indicators, level indicators and two indicators through setting calculation method, calculates four factors that influence the value of the primary and secondary factors for observation effect of Ideological and political course network teaching platform, provide the basis 
for improving the ideological and political course network teaching platform. The first level indicators are the 4 leading factors of university support, network teaching platform, teachers and students. The two level indicators are the subdivision indicators of 4 leading factors: University support, network teaching platform, teachers and students. The index comprehensive analysis method can be more comprehensive and accurate to reflect the influence degree of the various factors of the application of the network teaching platform in the ideological and political course.

According to the score of expert score, the score of the 4 leading factors is more uniform, and it is basically maintained at about 0.76 , but there is a difference. From the point of view, the construction of network teaching platform is the main factor influencing the operation status, its weight is 0.796 , and above the students on the ideological and political course network teaching platform running the deficiencies of cognition are basically the same, that network teaching platform construction lag is the main problem. University support is a secondary factor, and the impact weight is 0.785 . This indicates that factors such as slow network speed, small number of computer rooms and computer aging, and insufficient attention to the use of network teaching platform have hindered the effective implementation of the network teaching platform of Ideological and political education. The influence weight of teachers is 0.762 , has a significant impact on the teachers of Ideological and political course of network teaching platform for effective operation and function development, the use of the teaching platform has a guiding role, has the responsibility to promote and encourage the students to use the network ideological and political course teaching platform, at the same time in a timely manner to improve and adjust the teaching content, enrich teaching forms etc. Students' cognition, demand and input to the online teaching platform of Ideological and political education directly affect the platform application, but compared with the other three factors, the impact weight is relatively low (0.718).

Table 1. Level index weight

\begin{tabular}{|c|c|c|c|}
\hline Target layer & \multicolumn{2}{|c|}{ First level index } & weight \\
\hline \multirow{4}{*}{$\begin{array}{c}\text { The influence factors of } \\
\text { the network teaching } \\
\text { platform of the } \\
\text { ideological and political } \\
\text { course }\end{array}$} & University Support & $W_{g}$ & 0.785 \\
\hline & $\begin{array}{l}\text { Network teaching } \\
\text { platform }\end{array}$ & $W_{p}$ & 0.796 \\
\hline & Teachers' team & $W_{j}$ & 0.762 \\
\hline & Student & $W_{x}$ & 0.718 \\
\hline
\end{tabular}

Table 2. The influence degree of the two level index

\begin{tabular}{|c|c|c|c|c|}
\hline $\begin{array}{l}\text { Target } \\
\text { layer }\end{array}$ & $\begin{array}{l}\text { First level } \\
\text { index }\end{array}$ & \multicolumn{2}{|l|}{ Two level index } & $\begin{array}{c}\text { Influence } \\
\text { degree }\end{array}$ \\
\hline \multirow{12}{*}{$\begin{array}{c}\text { The } \\
\text { influence } \\
\text { factors of } \\
\text { the network } \\
\text { teaching } \\
\text { platform of } \\
\text { the } \\
\text { ideological } \\
\text { and Political } \\
\text { Course }\end{array}$} & \multirow{2}{*}{$\begin{array}{l}\text { University } \\
\text { support }\end{array}$} & Network infrastructure & $X_{g a}$ & 2.423 \\
\hline & & Related training & $X_{g b}$ & 2.276 \\
\hline & \multirow{4}{*}{$\begin{array}{l}\text { Network } \\
\text { teaching } \\
\text { platform }\end{array}$} & Convenience & $X_{p a}$ & 2.915 \\
\hline & & Resource richness & $X_{p b}$ & 2.454 \\
\hline & & Module integrity & $X_{p c}$ & 2.635 \\
\hline & & $\begin{array}{l}\text { Management and } \\
\text { maintenance }\end{array}$ & $X_{p d}$ & 2.657 \\
\hline & \multirow{3}{*}{$\begin{array}{c}\text { Teachers' } \\
\text { team }\end{array}$} & Degree of attention & $X_{j a}$ & 2.251 \\
\hline & & Teachers' propaganda & $X_{j b}$ & 2.352 \\
\hline & & Self use & $X_{j c}$ & 2.507 \\
\hline & \multirow{3}{*}{ Students } & Student cognition & $X_{x a}$ & 2.224 \\
\hline & & Student input & $X_{x b}$ & 2.165 \\
\hline & & Student needs & $X_{x c}$ & 2.406 \\
\hline
\end{tabular}


The determination of the influence degree of the two level index is based on students' preferences for each index. After the assignment of preferences, the results calculated by the above formulas are calculated. The result concentrates on the students' desire for the two level index and is also considered to be the student's score on the two level indicators. From the calculation results, we can see that the indicators with higher scores are mainly distributed in the construction of network teaching platform. Among them, the convenience, management and maintenance and module integrity of the ideological and political education online teaching platform are the 3 highest scoring indicators, which are 2.915, 2.657 and 2.635 respectively. As a whole, the students' score on the two level index is relatively low, which indicates that the students' cognition of the network teaching platform for the ideological and political course is less than that of the students.

\section{Ideas and Countermeasures to Strengthen the Construction of Network Teaching Resources in the Ideological and Political Theory Course of Colleges and Universities}

\section{Developing the Teaching Resources Module of the Ideological and Political Theory Course}

To give full play to the great advantages of the campus network, the construction of the campus network has been quite perfect. A series of teaching resources platform, such as educational administration system, library, excellent course teaching resources, has been collected. On this basis, the teaching resources of theoretical courses are shared on the Internet, providing help for the reform of teaching means and methods, and laying a solid foundation for the development of web-based courses. The establishment of ideological political course teaching resources of the network module should include: the name, course syllabus, teaching courseware, teaching materials, teaching case, reading practice requires a series of teaching resources, and these resources will be fully integrated to form a complete teaching resource library.

\section{Establishing Interaction and Communication Module between Teachers and Students}

WeChat lecture. WeChat provides a platform for brief comments and opinions related to the curriculum for college teachers and students. Micro-blog lecture. If the WeChat lecture is only a short point of view and an exchange of views, then, micro-blog provides a good platform for teachers to publish long views and views. The teacher can make a complete and detailed interpretation of the ideological and political theory on its own micro-blog for the shortcomings of the WeChat lecture, which is not detailed and unsystematic. Through the answer to the students' message, the interaction between teachers and students on the Internet is realized. Teachers can also explain the difficult problems in classroom teaching through micro-blog's continuing thematic training. The management department of University Ideological and political courses can also bring micro-blog lectures into the category of teacher assessment, so as to achieve the normalization of micro-blog lectures.

\section{Setting Up a Network Resource Teaching Platform with High Quality and Wide Coverage}

To establish a shared, high-quality, regional and national network resource teaching platform. First of all, to achieve high quality. The teacher in the release of teaching resources, must be responsible for their own achievements, because most of the students lack the ability to identify, so it requires teachers to create high quality, strict with oneself, and share teaching resources. Second, pay attention to sharing. Not my eyes only put in their own small circle, put in their own universities, pay more attention to the development of other regions of the country, and the world of network ideological and political education, through the establishment of a shared regional and national website, strengthen interaction, not only for academic exchange, is the exchange of ideas. The establishment of a shared web site will not only enrich the construction of the network resource base, but also make the academic exchange more convenient. In order to facilitate teachers and students to better understand the dynamic of teaching resources, it lays a solid foundation for the network teaching of Ideological and political theory. 


\section{Conclusion}

College Ideological and political theory course teaching resources of the network construction of network ideological and political course teaching can promote greatly, it can realize the further development of network ideological and political course teaching resources sharing, network political course teaching content, enrich the thinking to stimulate students' learning enthusiasm, improve the ideological and Political Theory Course Teaching of high school network effect.

\section{Acknowledgment}

Research on Deep Integration of Ideological and Political Education and Information Technology in the Era of AI from the 2018 annual reform project of Xi'an Peihua University(PHSZ1803)

\section{Reference}

[1] George Siemens. A World Without Courses [EB/OL]. www.elearnspace.org/media/worldwithoutcourses/player.html, 2008-03-06/2013-03-04

[2] Andrea Foster. Vendor of Educational Materials to expand E-book Offerings.Wired Champus:Chr onicle of Higher Education, 2008

[3] Ross, J.L.(1998)On-line but off course:a wish list for distance educators,International Electronic Journal For Leadership in

[4] Guang-ming Chen. Teaching Mode of Internet of Things in Colleges. Advanced Science and Industry Research Center. IEEE Internet Computing, vol. 5, issue 9, pp.25-31, 2017.

[5] Zou Shuilong. Exploration on Personnel Training Mode of Internet of Things under the universities Transformation and Development Background. Research Institute of Management Science and Industrial Engineering.Proceedings of 2017 3rd International Conference on Computer Science and Electronic Technology International Society, pp. 100-113, 2017.

[6] Liao Yiming. Research and application of sports management in computer aided school [J]. computer knowledge and technology, 2015, (09)

[7] Qin Yanjiao. Research on the application of Blackboard based network teaching platform [J]. China education informatization, 2008 (16): 67-69

[8] Dong Qiang. On the construction and application of network teaching platform for ideological and political courses in Colleges and universities [J]. Heilongjiang education, 2011 (10): 12-14

[9] Chen Xingdong. Research on the construction of network teaching platform for ideological and political education in Colleges and universities [J]. education exploration, 2011 (9): 100-101

[10] Yang Liyan, Chen Wenbin. Strengthening the construction of the network teaching platform for the ideological and political theory course in Colleges and universities [J]. ideological and political education research, 2012 (10): 103-105 